\title{
Solvency requirements effect on the financial performance of merged commercial banks in Rwanda: A Case of Banque Populaire Du Rwanda Public Limited Company (BPR) Atlas Mara
}

\author{
Rwakayigamba Patrick ${ }^{1 *}$ \& Dr Paul Munene Muiruri, PhD ${ }^{2}$ \\ $1^{*}$ MBA, Finance Student, Mount Kenya University, Rwanda \\ ${ }^{2}$ Lecturer, Mount Kenya University of Rwanda School of Business and Economic, Kigali Rwanda
}

\section{*Corresponding Author: -}

\begin{abstract}
: -
As the world is becoming global and competitive is growing at an increasing rate where firms are engaging themselves in the rivalry and banks are not left behind. One of the best strategies used by firms to penetrate into the competition is mergers. The purpose of the study was to evaluate the effect of solvency requirements on merged commercial banks in Rwanda guided by shareholder's wealth maximization theories, Trade-off theory of capital structure and the theory of Modigliani and Miller. The targeted population was 70 employees of BPR Rwanda Atlas Mara. The sample size was picked from the different departments by the help of purposive sampling technique. The researcher used the questionnaires to gather data and also the published information from the company websites and the data analysed using Statistical Packages for Social Sciences (SPSS) version 21. The findings on solvency requirement had influence on the financial performance after merger efforts and the overall mean of 3.138 agreed with the statement. The Spearman's Rho correlation coefficient is 0.674 implying that the variables used in subsequent regression modelling are not similar and thus, there are no multicollinearities. This means that $67.4 \%$ of the changes in the financial performance of firms is being affected by the merger process. The regression results indicated that the coefficient is positive (0.79) and the significant levels are less than 0.05 ( $P$-value=0.0033). This indicates that banks engage in various merger activities in order to improve their financial performance. The study concludes that solvency requirements contribute to financial performance of commercial banks in Rwanda. The researcher recommended that banks should engage themselves in merger activities in order to maintain the competition since it got a bigger effect concerning the performance improvements.
\end{abstract}

Keywords: Solvency Requirements, Financial Performance, Merged Commercial Banks

\section{(우 $($ (1)}




\subsection{INTRODUCTION}

Mergers is seen to be a crucial cash related instrument that empowers companies to develop speedier and give returns to firms and investors within the advanced global economy, (Nima, 2015). Normally, merger is clarified as the change in possession, commercial enterprises, asset merging and organization with the aim of increasing shareholders' esteem and enhances the business performance, (Ogada, Njuguna \&Achoki, 2017).

A number of studies like (Njambi \& Kariuki, 2018) suggest that one of the foremost factors of progressing firm's performance is the outstanding in mergers. Thus, they described merger as the total maintenance of single entity by the other, hence the acquiring business holds the personality and the acquired business cease to live. Two strands of empirical literature suggest both positive and negative impacts of bank mergers. The second strand of literature provide evidence that not every merger is useful because of weak organization of the challenges amid post-mergers. For instance, Wanguru (2011) conducted a study on the benefits of mergers to the Kenyan firms centering on firms that experienced amalgamation amid 2004 and 2008 and the findings were that, a couple of the mergers firms' financial performance diminished within the post-merger time, for others had shown superior benefits within the post-merger after the merger. The financial performance indicates how good a company utilizes its resources from essential techniques of trade to produce incomes for a particular period of time (Moynihan \& Pandey, 2010). Even though several literatures have been conducted about the benefits of coming together of firms over their financial performance as being indicated above, it remains silent on these issues in the Rwandan banking industry context. Thus, omission from the literature might be misleading for a number of reasons. That is to say, like any other East African countries, in Rwanda the banking industry have come together with many cases of mergers over the previous decade. For illustrations, in 2012 BCR was acquired by I\&M bank, in 2008 Bancor acquired by Access bank, in 2007 BCDI acquired by Ecobank, Banque Populaire du Rwanda was merged with Atlas Mara investment group to become BPR Atlas Mara, in 2011 Agaseke Bank was acquired by Bank of Africa group Rwanda Limited and conversion to a Commercial bank, Attijariwafa Bank was acquired by Cogebanque. It is revealed that, the majority of the acquirer's foreign owned banks.

Thus, few scholarly attempts have been made to navigate the benefits mergers and acquisitions on the commercial bank's financial performance in Rwanda. Among those include; Uwizeye, (2016) conducted a study on how mergers and acquisition has benefited firm's financial health, Gakwandi and Kule (2015) researched on the influence of mergers and acquisition strategy on the financial performance of financial institutions in Rwanda, Harindintwari. Shukla and Odour (2015) researched on the contribution of mergers on portfolio effectiveness and efficiency of government institutions of Rwanda. However, they did not focus on what level has the firm's mergers contributed to the financial performance of the Rwandan financial institutions particularly commercial banks. Hence, researcher's contribution is to empirically provide the evidence on the likely benefits of mergers on the performance of commercial banks in less developed country context of Rwanda by using BPR Atlas Mara as one of those commercial banks which has managed to go through mergers process.

\subsection{Problem Statement}

In globe is a lot of unforeseen circumstances such as faster technological improvements, competition, threats and strive for the accessible chances has made banks to go for alternatives strategies such mergers. Merger strategy help bank to competitive over their competitors. Merger's process is anticipated to contribute in satisfying competitive advantage of the banks (Koech, 2013). In Rwanda, Atlas Mara merged BPR after acquiring shares from existing shareholders and merging the bank with the commercial banking business that was written off by in 2016, Banque Populaire du Rwanda recruited almost 3.400 employees by that period, moreover, after acquisition has taken place by Atlas Mara and the merger with BRD Commercial, about 3,000 employees were being terminated. In April 2019, the bank faced financial constraints whereby Equity Bank Group acquires 62 percent of Banque Populaire du Rwanda, in a share swap with the Atlas Mara Limited. By the year 2015. Banque Populaire du Rwanda had made net interest income of (49.4\%) and net income of $(4.1 \%)$ after the merger took place in the year of 2016 there was a decline of net interest income of $(45.2 \%)$ and the net income of $(1.2 \%)$.

Few scholarly attempts have been made to navigate the effects of mergers on the commercial bank's financial performance in Rwanda. Among those include; Uwizeye, (2016) conducted a study on how mergers and acquisition has benefited firm's financial health, Wanguru (2011) did study in Kenya, Kaur (2014), Ning and Wang, (2014) Chinese intercontinental takeovers. Gakwandi and Kule (2015) researched on the influence of mergers and acquisition strategy on the financial performance of financial institutions in Rwanda, Harindintwari. Shukla and Odour (2015) researched on the contribution of mergers on portfolio effectiveness and efficiency of government institutions of Rwanda. However, they did not focus on solvency requirements effects on the financial performance of merged commercial banks in Rwanda. To determine the solvency requirements effects on the financial performance of merged commercial banks in Rwanda.

\subsection{Literature Review}

Solvency is said to be one of the particular components upon the performance of a bank. A firm whose total obligations transcends its assets is considered to be technically bankrupt. It is found out that a bank can become bankrupt in case it cannot meet its long-term liabilities. This implies that it might be unable for the bank to refund its creditors. This can occur in case client's default on their loans for a given length of time, a condition which might lead to bank operations. One of the major financial ratios being used for measuring the solvency of the bank is the ratio of debt to equity. The ratio presents the extent to which financial leverage is used by the bank and involves both short- term and long-term debt (Mburu,2015). 
Different motives raised for mergers are to match the developing market request and competence, broaden to comprehensive markets, utilize the rising unused and costly advanced technological systems, or to link up with the modern starting capital needed by the controllers like the segment of banks (Kithinji \& Waweru, 2010). Ireri (2011) analyzed on an overview about the effects of mergers alongside with the financial performance of oil firms in Kenya and thus, the investigators' finding concluded that the mergers and financial performance were directly related after the merger. Kithitu and Mokamba, (2012) examined on the portion of mergers on the working of Kenyan commercial banks. The findings revealed that mergers incorporate value to the wealth of shareholders.

The second strand of literature provides evidence that not every merger is useful because of weak organization of the challenges amid post-mergers. For instance, Wanguru (2011) conducted a study on the benefits of mergers to the Kenyan firms centering on firms that experienced amalgamation amid 2004 and 2008 and the findings were that, a couple of the mergers firms' financial performance diminished within the post-merger time, for others had shown superior benefits within the post-merger after the merger.

The Financial performance indicates how good a company utilizes its resources from essential techniques of trade to produce incomes for a particular period of time (Moynihan \& Pandey 2010). The main computation of financial health incorporates: Net margin which measures benefits, because it includes all costs into consideration. That is to say, all expenses plus earnings and payments of tax. Gross margin which quantifies how much cash that a firm made after expenses have been considered, operating profit margin fits among the gross and net measures of equating benefits after operating costs are subtracted before interest and taxes mergers is clarified as the movement for which two and above firms decides to come as one and works as one to realize the key goals or objectives like asset sharing, asset utilization, benefits of diversity or minimization of cost or any other working or monetary benefits for both firms. (Salim, 2011). A merger is basically the coming together of two firms that first worked as separate entities. The assets and resources of the two companies become one under one control that the two companies are to some extent superior compared to when they operate as separate companies (Misigah, 2012). Also, ownership is shared among the beginning shareholders.

Normally, acquisition is whereby one company takes over another and makes it part of it. The motive behind mergers is that the combined entity is superior to the total of the isolated entities. Firms which are financially a strong may in this way buy other firms with the aim of making strong competence, profit making firm, whereas target firms may see as an elude course to durability. In spite the fact that mergers being efficiently marketed, in reality the previous refers to a business merging where by a starting business with unused identity is shaped from the combining firms through putting together of common shares, currency or two of them like amalgamation of business of equals (Kayombo, 2019).

The critical review deals with the profound examination of distinctive literary works as being conducted by the analyst concerning the subject managed with. Moreover, this done all through weighing the victory and disappointments and distinguishes the gap. Pezaro (2020) characterizes critical success factors as "the confined number of areas in which results, in case they are satisfactory, will guarantee effective competitive performance for the organization". He shows that CSFs (critical success factors) could be valuable approach for distinguishing data prerequisites for the administration. The table 1 elaborates more about the different empirical literatures, their findings and the research gaps.

Table 1: The critical side of different empirical studies

\begin{tabular}{|c|c|c|c|c|}
\hline Author & & Country & Variables & Research Gaps \\
\hline $\begin{array}{l}\text { Amu } \\
\text { Chigbu }\end{array}$ & $\&$ & Nigeria & $\begin{array}{l}\text { Mergers and The results were financial that, there } \\
\text { was a performance tangible increase in the } \\
\text { earnings of the firm compared to that of before }\end{array}$ & $\begin{array}{l}\text { The researcher did not indicate what } \\
\text { really caused an increase in bank } \\
\text { earnings to avoid future hardships. }\end{array}$ \\
\hline
\end{tabular}

\begin{tabular}{|c|c|c|c|c|}
\hline \multirow[t]{3}{*}{ Ndung'u (2011) } & \multirow[t]{3}{*}{ Kenya } & \multicolumn{2}{|c|}{ Bank mergers The findings } & \multirow{3}{*}{$\begin{array}{l}\text { There is no empirical indicators of } \\
\text { how the bank had to manage } \\
\text { boosting of income from before and } \\
\text { after mergers }\end{array}$} \\
\hline & & \multirow[t]{2}{*}{$\begin{array}{l}\text { andfinancial } \\
\text { performance }\end{array}$} & $\begin{array}{l}\text { indicated a great } \\
\text { improvement within the } \\
\text { bank's }\end{array}$ & \\
\hline & & & $\begin{array}{l}\text { financial performance } \\
\text { during the postmerger }\end{array}$ & \\
\hline Abbas et al (2014) & Pakistan & $\begin{array}{l}\text { Mergers and } \\
\text { financial performance }\end{array}$ & $\begin{array}{l}\text { The findings reported that, } \\
\text { there was a decline the bank's } \\
\text { financial performance after } \\
\text { merger process. }\end{array}$ & $\begin{array}{l}\text { There was no reason being provided } \\
\text { sfor the decline in bank's } \\
\text { r performance }\end{array}$ \\
\hline Wanguru (2011) & Kenya & $\begin{array}{l}\text { Mergers and bank } \\
\text { profitability }\end{array}$ & $\begin{array}{l}\text { The findings indicated a } \\
\text { decline in performance after } \\
\text { mergers }\end{array}$ & $\begin{array}{l}\text { There were no reliable figures being } \\
\text { provided for the decline in bank's } \\
\text { earnings and which area that } \\
\text { affected the process. }\end{array}$ \\
\hline
\end{tabular}


Table 1 shows the different studies that were carried out by different researchers on mergers and financial performance of banks from different areas of the globe. From the previous literatures within the above table, most of the studies were being carried about the effects of mergers and the bank's financial performance and the results are contradicting each other since some shows and improvement in financial performance and others indicating the decline. Thus, there is no clear empirical figures since there's no valid and reliable information that might have caused the variation within the financial performance of banks.

\subsection{Theoretical Framework}

Trade-off theory of capital structure and the theory of Modigliani and Miller (1963) guided the study. The theory of tradeoff theory of capital structure for which the firm decides how much debt finance and how much equity finance by weighing up the costs and gains. The major objective of the theory is to clarify the reality that companies normally are being financed partially with debt and partially with equity. This asserts that there is a benefit to financing with debt, the tax benefits of debt and there is a cost of financing with debt, the costs of financial difficulties whereby, among those are bankruptcy costs of debt and nonbankruptcy costs. Thus, the trade of theory was truly considered after the discussions of Modigliani-Miller (Ahmadimousaabad, et al. 2013).

The theory of Modigliani and Miller (1963) speculates that for complete retails, no matter what funding system an entity employee to fund its functioning. They speculated that retail esteem for the company could be decided in relation with the gaining control along with threats of its basic resources including its values. This asserts that, an assured market value prepare the standard random succession, within the non-payment of taxes, liquidation value, office charges, and unrelated information, along with productive merchandise ,also the esteem of an industry is not influenced through which the business is funded. It does not matter if the company's wealth is lifted by authorized shares or offering obligation. This does not mind what the company's profit policy is. This research will contribute to indicate how expanded capital base affects the large performance. In this way, this theory ought to include esteem to the research for it will explain how capital base will impact finance.

\subsection{Method}

A Research design is the general overview which clarifies the process and procedures for gathering and analyzing the required data that is to say, it provides a framework or plan of action for the research (Rizvi \& Bhardwaj, 2019). The study adopted a descriptive research design. The target population for the research was 70 employees of BPR ATLAS Mara and included heads of departments, legal officers, consultants, senior top officials and risk officers. The study considered the period during the merger and acquisition-taking place from 2016 to 2021. The sample size was 70 respondents who makes the entire population, where the choose sample of respondents are including employees who are charged and those who were involved during mergers process of BPR Atlas Mara and also have got to know how it has affected financial performance of the bank, at that point the researcher will select the population sample size by using of purposive sampling which is also recognized as judgmental sampling which depends on the judgment of the researcher when it comes to choosing the group as per the researcher's personal interest.

The questionnaires were used as the tool of data collection so as to obtain the relevant information within the most reliable and valid manner. Hence, the accuracy and consistency of the survey forms an important strand of research methodology. The administration procedures were conducted as; the research used interview guide for the middle level and operational level managers the researcher will use questionnaires. The researcher went to their offices and introduce himself before distributing the questionnaires and explaining the purpose of the study to them. Finally the researcher gave them time to fill the questionnaire and return the answers. Secondary information was obtained through visiting bank website and library.

The statistical, analytical, descriptive and synthetically research methods for data analysis that offer the opportunity to measure and quantifies the results of research. Percentages and frequencies were used to analyze the demographic kind of information from the respondents, mean and standard deviation will also be used in analyzing the Likert scale items for the each study variables. The researcher used both correlation coefficient analysis to determine the solvency requirement effects on the financial performance of merged commercial banks, the inferential statistical tools will be adopted. To determine the relationship between solvency requirements effect on the financial performance of merged commercial banks in Rwanda, the researcher used regression model illustrated as;

$$
\begin{aligned}
& y=\beta 0+\beta_{1} X_{1}+\alpha \text { Where } \mathrm{Y} \text { is Financial performance of commercial bank } \mathrm{X}_{1} \text { is Solvency requirements, and } \\
& { }_{1}=\text { Regression coefficients. Thus, after which the data was analyzed and interpreted by utilizing SPSS. }
\end{aligned}
$$

\subsection{Results}

The questionnaire was administered to seventy respondents in Banque Populaire. Only seventy questionnaires were filled and collected from respondents accounting for $88 \%$ of the response rate. The following sections pertain to the analysis of descriptive (demography, measures of central tendency and dispersion) and analytical (correlation and regression) results. Table 2 presents demographic characteristics of respondents. The highest percentage of the respondents were male constituting $78 \%$ of all respondents and $22 \%$ of the respondents are females. In addition, $20 \%$ of the respondents are senior managers, $33 \%$ are middle level managers and a big percentage of the respondents are general staff in the bank. Table 2 also show that majority of the respondents hold bachelor's degree (58\%) while those with masters are $24 \%$ of the respondents. $6 \%$ hold professional certificates, $9 \%$ hold bachelors and professional and the remaining percentage (3\%) are those having both masters and professional certificates. Lastly, Table 2 reports demographic characteristics in terms 
of experience of respondents. Majority of the respondents have between 5-10 years of experience (61\%) and 29\% gave between 11 and 15 years. Few respondents have than 7 years of experience in the bank (7\%) and also those with more than 15 years of experience are $3 \%$ of the respondents.

Table 2: Demographic characteristics of respondents

\begin{tabular}{|c|c|c|}
\hline _Gender & Frequency & Percentage \\
\hline Male & 54 & 78 \\
\hline Female & 16 & 22 \\
\hline Total & 70 & 100 \\
\hline \multicolumn{3}{|l|}{ Job position } \\
\hline Senior managers & 14 & 20 \\
\hline Managers & 23 & 33 \\
\hline Staff & 33 & 47 \\
\hline Total & 70 & 100 \\
\hline \multicolumn{3}{|l|}{ Education $\quad$ Bachelors } \\
\hline & 41 & 58 \\
\hline Masters & 17 & 24 \\
\hline Professional & 4 & 6 \\
\hline Bachelors + Professional & 6 & 9 \\
\hline Masters + Professional & 2 & 3 \\
\hline Total & 70 & 100 \\
\hline \multicolumn{3}{|l|}{ Experience } \\
\hline Less than 5 years & 5 & 7 \\
\hline $5-10$ years & 43 & 61 \\
\hline $11-15$ years & 20 & 29 \\
\hline \multirow[t]{2}{*}{ Above 15 years } & 2 & 3 \\
\hline & 70 & 100 \\
\hline
\end{tabular}

\subsection{Presentation of Findings}

This section analyzes the descriptive results from respondents' views on statements pertaining to capital requirements, solvency, financial leverage, asset requirements and their effect on financial bank of Banque Populaire Atlas Mara. Table 3 reports results on statements pertaining to capital requirements as one of the indicators of merger effects. On average, respondents agree that the bank have been able to raise more capital resulting from the merger efforts $($ Mean $=3.65$, $\mathrm{SD}=0.80)$. Results also show that the bank has been able to make enough profits resulting from the merger $(\mathrm{Mean}=3.65$; $\mathrm{SD}=0.78$ ). On average the bank has also been able to attract more deposits, has improved liquidity, improved efficiency, and the bank has been to acquire more advanced technological systems, and has gained many sources of income. 
Table 3: Response's on Solvency requirements and financial performance

\begin{tabular}{|c|c|c|c|c|c|c|c|}
\hline $\begin{array}{l}\text { Solvency requirements and financial } \\
\text { performance }\end{array}$ & 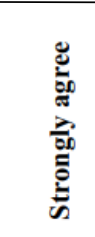 & 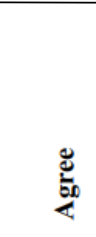 & 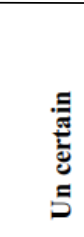 & 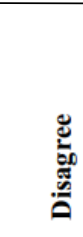 & 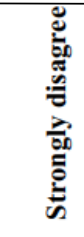 & $\stackrel{\Xi}{\Sigma}$ & के \\
\hline & $\partial^{0}$ & $e^{0}$ & & $\partial^{0}$ & $\partial^{0}$ & & \\
\hline $\begin{array}{l}\text { The bank has purchased enough } \\
\text { resources as a result of mergers }\end{array}$ & $57.1 \%$ & 28.6 & $8.6 \%$ & $5.7 \%$ & $6.7 \%$ & 3.483 & 0.815 \\
\hline $\begin{array}{l}\text { The number of our bank's liabilities } \\
\text { have been minimized as a result of } \\
\text { increased assets }\end{array}$ & $66 \%$ & $28.6 \%$ & $4.3 \%$ & $1.4 \%$ & $0 \%$ & 3.397 & 0.850 \\
\hline The bank's assets have increased & $57.1 \%$ & $28.6 \%$ & $10 \%$ & $4.3 \%$ & 0 & 3.638 & 0.759 \\
\hline $\begin{array}{l}\text { The bank's creditors have gained } \\
\text { trust within their bank }\end{array}$ & $71.4 \%$ & $14.3 \%$ & $8.6 \%$ & $5.7 \%$ & $4 \%$ & 3.190 & 0.540 \\
\hline $\begin{array}{l}\text { The bank has gained stability } \\
\text { financially }\end{array}$ & $51.4 \%$ & $37.1 \%$ & $8.6 \%$ & $3 \%$ & $6.7 \%$ & 3.707 & 0.788 \\
\hline $\begin{array}{l}\text { The bank has gained enough funds } \\
\text { and made much profits }\end{array}$ & $51.4 \%$ & $37.1 \%$ & $8.6 \%$ & $3 \%$ & $0 \%$ & 3.724 & 0.805 \\
\hline
\end{tabular}

Results from Table 3 presents that, the respondent's view on the statement that the bank purchased enough resources after merger were that, $57.1 \%$ of the respondents strongly agreed with the statement, $28.6 \%$ of them agreed with it and $8.6 \%$ of the respondents strongly disagreed with the statement while $5.7 \%$ of them disagreed with it. The results also indicates that the respondent's view on the statement that the number of bank's liabilities have been minimized as a result of increased assets were, $66 \%$ of the respondents strongly agreed with the statement, $28.6 \%$ of them agreed with it and $4.3 \%$ of the respondents strongly disagreed with the statement while $1.4 \%$ of them disagreed.

Table 3 results indicates that the respondent's view on the statement of the bank's assets have been increased are; $57.1 \%$ of the respondents strongly agreed with the statement, $28.6 \%$ of them agreed with it and $10 \%$ of the respondents strongly disagreed with the statement while $4.3 \%$ of them disagreed with it. The results also from the Table 4.3 shows that $71.4 \%$ of the respondents strongly agreed with the statement that the bank's creditors have gained trust within their bank, $14.3 \%$ of the respondents agreed with it and $8.6 \%$ of the respondents strongly disagreed with the statement while $5.7 \%$ of them disagreed with the statement.

On the respondent's that the bank has gained stability financially indicates that, $51.4 \%$ of the respondents strongly agree with the statement, $37.1 \%$ of the respondents agreed with statement and $8.6 \%$ of the respondents strongly disagreed with the statement while $3 \%$ of them disagreed with the statement. Results showed that $51.4 \%$ of the respondents strongly agreed with the statement that, the bank gained enough fund and made much profits, $37.1 \%$ of the respondents agreed with the statement and $8.6 \%$ of the respondents strongly disagreed while $3 \%$ of them disagreed with the statement.

Basing on the obtained results from Table 3, the biggest percentage of the respondents agreed with the statements and thus, this implies that the solvency requirement have got the positive significant of the financial performance of banks and there has been a great improvement after merger process. On average, respondents agree that the bank has been able to acquire enough resources resulting from mergers (Mean=3.483; $\mathrm{SD}=0.815$ ). The bank has been able to meet its dayto-day obligations as a result of merger (Mean=3.397; $\mathrm{SD}=0.850$ ). Results also show that the bank has been able to increase on the number of assets resulting from mergers on average (Mean=3.638; SD=0.759). Financial stability was gained after the merger (Mean=3.707; $\mathrm{SD}=0.788$ ).

\subsection{Inferential statistics}

The objective of the study is to determine the solvency requirement effect on the financial performance of merger commercial banks. To meet this objective, some analytical tests are performed namely correlation and regression models. Results reported in Table 4 show that overall, the Spearman's Rho correlation coefficient as follows

Table 4: Correlation matrix

Solvency requirements

\begin{tabular}{lll} 
& & Solvency requirements \\
\hline \multirow{3}{*}{ Solvency requirement } & N & \\
& Pearson Correlation & 1 \\
& Sig.(2-tailed) & \\
& N & \\
financial performance & Pearson Correlation Model & $.493^{* *}$, \\
& Sign. (2-tailed) & 0.00 \\
\hline
\end{tabular}


Findings presented in Table 4 reveal correlation between variables. For Financial leverage and financial performance there had moderate positive significant correlation $(\mathrm{r}=.493 * *, \mathrm{p}=0.00)$. This study further assesses the solvency requirement effects on the financial performance of merged commercial banks in Rwanda. Model results are presented in Table 5 and 6.

Table: 4 Analysis of variance

\begin{tabular}{llllll}
\hline Mo & Sum of Squares & Df & Mean Square & F & Sig. \\
1 Regression & 8.97 & 4 & 224 & 207.407 & $.002^{\mathrm{a}}$ \\
Residual & 5.185 & 66 & 1.08 & & \\
Total & 14.155 & 70 & & & \\
\hline
\end{tabular}

a. Predictors: (Constant), Solvency requirements

b. Dependent Variable: financial performance

From the above table, findings indicates that overall, merger effect increases financial performance. The model between merger effect and financial performance of Rwandan commercial banks shows that model was significant since the $\mathrm{p}$ value was less than 0.05 without the interaction term, $F(4,66)$ was $207.407 \mathrm{p}<.002$

Table 6: Regression Coefficients

\begin{tabular}{|c|c|c|c|c|c|}
\hline \multirow[b]{2}{*}{ Model } & \multicolumn{2}{|c|}{ Unstandardized Coefficients } & \multicolumn{2}{|c|}{$\begin{array}{l}\text { Standardized } \\
\text { Coefficients }\end{array}$} & \multirow[b]{2}{*}{ Sig. } \\
\hline & B & Std. Error & Beta & $\mathbf{T}$ & \\
\hline 1 (Constant) & 3.22 & 1.782 & & 1.87 & 0.0046 \\
\hline Solvency requirements & 1.892 & 0.921 & .883 & 3.33 & 0.046 \\
\hline
\end{tabular}

The independent variables are capital requirements, solvency requirements, and financial leverage and asset requirements. The dependents variables being financial performance. Therefore, the equations used within the study are as follows: two variables, the researcher used regression model being illustrated as;

$$
y=\beta 0+\beta_{1} X_{1}+\varepsilon
$$

After analysis it becomes financial performance $=3.22+1.892$ solvency requirements

The interpretation result from findings in table 4.14 indicate that holding independent variables (solvency requirements) is financial performance is 3.22 unit of solvency requirements will lead to increase of financial performance by a factor of 1.892. The findings indicate that financial performance of commercial banks is being affected by mergers. Particularly findings present that mergers moderately and positively affects the financial performance of commercial banks. According to the table 6 the results showed that relationship between solvency requirements and the financial performance of commercial banks in Rwanda had p-value is $0.046<0.05$. Hence we reject the null hypothesis and concluded that there is no significance effect between solvency requirements and the financial performance of commercial banks in Rwanda

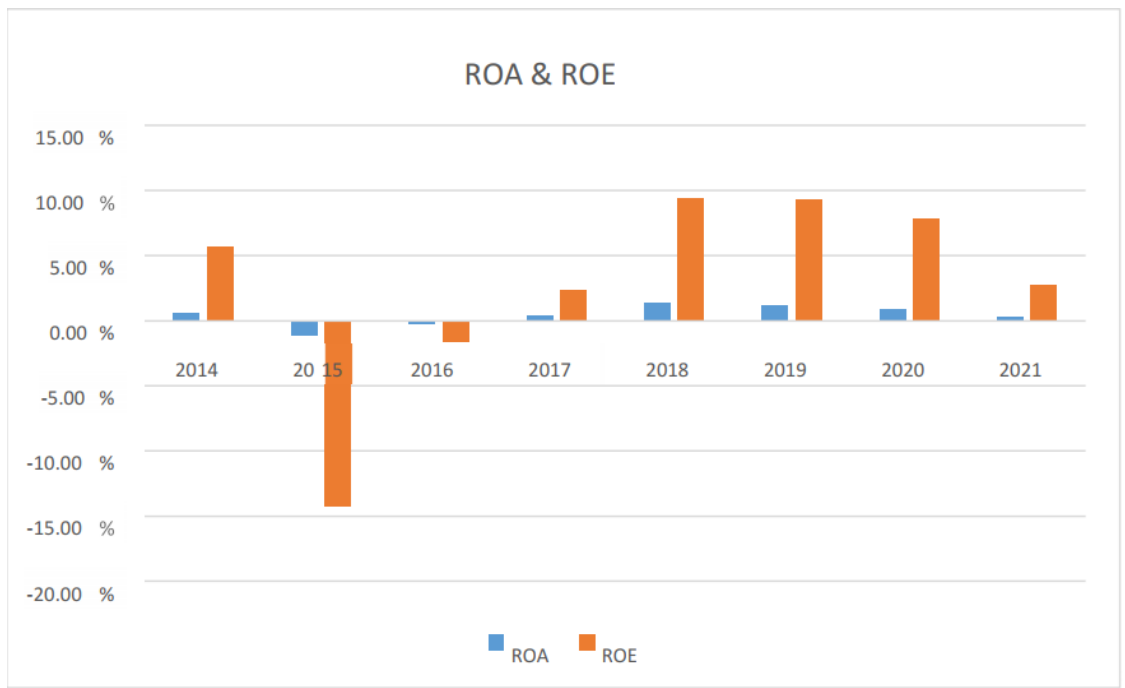

Figure 1: Financial perfomance

Figure 1. reports results for return on assets (ROA) and return on equity (ROE) respectively during the period 2014 to 2019. Return on assets show a significant decrease in 2015 and 2016 resulting from a decrease in net income during this 
period. In the subsequent years, the ratio significantly increases from $0.38 \%$ in 2017 to $1.21 \%$ in 2020 . Return on equity also shows the same but higher decrease in 2015 and 2016 resulting from the decrease in net income during the same period. The two ratios are adversely and positively affected by the changes in net income respectively. In summary, the analysis of secondary data show that there was performance resulting from the merger activities. The results in Figure 1 support earlier results analyzed from primary data that merger efforts significantly improves bank performance.

\subsection{Conclusion}

The second of objective of the study is to evaluate the evaluate the extent to which solvency has affected the financial performance and the findings reports that, there is a positive effects on the performance of the bank in that it managed to secure enough resources resulting from merger efforts (Mean=3.483; SD=0.815), and the bank's liabilities have been minimized due to an increased number of assets( Mean=3.397; SD=0.850) and

(Mean=3.638;SD=0.759), through bank merger process, financial stability have been registered substantially $(\mathrm{Mean}=3.707 ; \mathrm{SD}=0.788)$ and much profits were also obtained as a result of merger $(\mathrm{Mean}=3.724 ; \mathrm{SD}=0.805)$. Depending on the average this implies that mergers contributes a lot on the financial performance of the firm.

The findings indicates that, banks are driven by diverse motives and parameters of merger process in Rwanda to boost their performance and those including solvency, Return on Equity and Return on Assets whereby, on average the results show that there has been and improvements in the performance of the bank. The results imply that merger efforts have a bigger effect on the financial performance of the firm. On the side of policy point of view, the study suggest that the bank owners should add more energy in looking forward in collecting information concerning the use of different merger techniques that could help them since mergers positively and significantly improves the performance of bank.

\subsection{Recommendation}

The shows that the post-merger is so important and the banks and other firms should take actions as in engaging themselves in merger. The study recommends that the net income should be considered with due diligent during merger process as in cutting the cost structure so that the performance is not affected negatively. Banks should consider raising more revenues which is as a result of merger efforts. To acquire long-term loans, banks should put more efforts in merging since this helps them to gain strength and facilitates them to obtain the huge loans to enable them improve their financial performance.

\section{REFERENCES}

[1].Abbas, Q, Hunjra, A. I, Azam, R. I, Ijaz, M. S \& Zahid, M. (2014). Financial performance of banks in Pakistan after Merger and Acquisition. Journal of Global Entrepreneurship Research, 4(1), 13.

[2].Amu, C, U \& Chigbu, E, E. (2015). Relationship between Pre and Post Merger and Acquisition Banking Industry Performance in Nigeria. Independen Journal of Management \& Production, 6(3), 850-865

[3].Misigah, G. (2012). Effects of mergers and acquisition on growth: A study Commercial Banks in Kenya, (Doctoral dissertation, Kenyatta University).

[4].Michael,N. B. (2013). Bank mergers and acquisition and shareholders' wealth maximization in Nigeria. Journal of applied Finance and Banking, 3(3), 255.

[5].Modigliani, F, \& Miller, M. H. (1963). Corporate income taxes and the cost of capital: a correction. The American economic review, 53(3), 433-44.

[6].Mutumira, A. M. (2019). Effect of capital adequacy on the financial performance of insurance companies in Kenya. International Academic Journal of Economics and Finance, 3(4), 172-185

[7].Nalzaro, L. M. (2012). Chapter 8-Sample and Sampling Techniques". Slides-Share http://www.slideshare. net/ludymae.

[8].Neena,S. (2010). "Measuring post-merger and acquisition performance": An investigation of select financial sector organizations in India. International journal of Economics and Finance, 2(4), 190-200.

[9].Nima, F. H. (2015). Effect of mergers and acquisitions on the financial performance of commercial banks in Kenya. Doctoral dissertation, University of Nairobi.

[10]. Njambi, F. N. U, \& Kariuki, P. W. O. (2018). "Effect of mergers and acquisitions of financial performance of financial institutions in Kenya". International Academic Journal of Economics and Finance, 3(1), 6479.

[11]. Ogada, A, Njuguna, A, \& Achoki, G. (2016). "Effect of Synergy on Financial Performance of Merged Financial Institutions in Kenya". International Journal of Economics and Finance, 8(9), 199-207.

[12]. Salim, B. (2011). “A study on strategic initiatives and actions taken during abanking Merger". International Journal of Emerging Sciences, 1(3), 246. 